\title{
TITLE INTERTEXTUALITY IN RAY BRADBURY'S WORKS
}

\author{
CMansurov R., ORCID: 0000-0001-5666-8374, Uzbek State World Language Literature, \\ Tashkent, Uzbekistan, Mansurovr92@gmail.com
}

\section{ИНТЕРТЕКСТУАЛЬНОСТЬ В ЗАГЛАВИЯХ ПРОИЗВЕДЕНИЙ РЕЯ БРЭДБЕРИ}

(СМансуров Р. Д., ОRCID: 0000-0001-5666-8374, Узбекский государственныий университет мировых языков, г. Ташкент, Узбекистан, Mansurovr92@gmail.com

Abstract. This article deals with the concept of intertextuality in the titles of Ray Bradbury's short stories. It reflects the ideas of intertextuality in general, intending to define them through the examples of his short stories. It intends to explain why the author uses title intertextuality while decoding the plot of his short stories and the referred text. Through four stories, "There will come soft rains", "Some live like Lazarus" "I sing the body Electric" "Perchance to dream" (also called "Asleep in Armageddon") we find what role an intertext plays, being used in the title of the work and how it should be seen as an intertexuality as being as reference tool in new texts. That in turn helps us to understand the author's mastery extend who while writing new texts that would refers to other texts in his title. Along the way, we will witness the value of science-fiction and its usage in his works.

Аннотащия. В статье разбирается концепт использования интертекстуальности в названиях литературного произведения в работах Рейа Брэдбери. В статье рассматривается само понятие интертекстуальности, как концепта применения для более глубокого понятия других текстов. Примеры текстов взяты из коротких рассказов Брэдбери: Будет ласковый дождь (“There will come soft rains"), Кое-кто живет как Лазарь ("Some live like Lazarus”) Электрическое тело пою!(“I sing the body Electric”) Уснувший в Армагеддоне ("Perchance to dream” also called “Asleep in Armageddon”) и благодаря этим произведениям мы попытались показать как важна интертекстуальность в работах Рей Брадбери. А так же, увидим значимость научной фантастики в работах Рейа Брэдбери.

Ключевые слова: интертекст, Рей Брэдбери, концепт, интертекст как названия произведения, аллюзия

Keywords: intertextuality, Ray Bradbury, concept, title intertextuality, allusion, direct and indirect intertext.

Before we start to securitize Ray Bradbury's works to identify the elements of intertextuality, we should clarify a certain definition under which "intertextuality" is understood as there are many ways to define this word. J. Kristeva in the second half of the $20^{\text {th }}$ century wrote a significant work defining the intertextuality in her essay "Word, Dialogue, and Novel," where she pointed out that "Any text is constructed of a mosaic of quotations; any text is the absorption and transformation of another". Roland Barthes later on pointed out a new look with his notion of an authorship in his essay "The Death of Author," where he claimed that text is not original work as we saw it in the 
past, but rather chunks and pieces of other texts that existed before it. Thus, intertextuality is a key that helped to create others texts and texts before it.

Taking the notion of the word "sin", we look into the concept that was created quite long time ago, and if we see this notion in recently written books or in any other text, we automatically refer to the first appearance of the word itself, we bound the meaning to the first reference, with which we correlate the meaning of the new written book. Thus intertextuality is a key which would give a reader a chance to decipher a new text with the usage of an older text, and so on. In order to fully understand the usage of intertextuality we are going to analyze works written by Ray Bradbury and how he uses the intertextuality to deliver and to extend the meanings of his works.

Ray Bradbury is considered as one of the prominent writers of the $20^{\text {th }}$ century, his mastery still attracts young researches to his works like the moths to the lamp. Most of his works full of intertextuality that is used intentionally to broaden our grasp for the deeper meanings which are stored within his short stories, novels.

Thus we shall start with the story "Perchance to Dream (Asleep in Armageddon) written by Ray Bradbury in the collection Planet Stories (1948).

The story has two titles and both of them add needed meaning into the text. The plot of the story revolves around the astronaut who had to land on mysterious PLANETOID 787. After crash, main character Leonard Sale meets mysterious "habitants" of this planetoid. It is interesting that these habitants have lost their physical form, and their thoughts, feelings and mind remains in nonphysical form. The question is how they lost their body and why they have to exist in this planetoid is revealed later on when main the character decides to sleep after sending SOS signal to Marsport. A ship from Marsport was supposed to arrive in six days, he had enough supply of food and oxygen, and thus he decided to sleep. As soon as he falls asleep the habitants reveal themselves in the dream of Sale introducing themselves as warriors of two armies - one is "I am Tylle of Rathalar. Proud Tylle, Tylle of the Blood Mound and the Death Drum. Tylle of Rathalar, Killer of Men!» while other names himself as «I am Iorr of Wendillo, Wise Iorr. Destroyer of Infidels![ Perchance to Dream by Ray B. J These two leaders have fought with one another over 5000 years, and still would have been fighting if their mighty, beautiful, self-sufficient planet was not destroyed by their war. Only through science they were able to survive, and to be alive. Leonard Sale's mind was playground for these two mighty warriors and for their army, as their dispute was not over. Even when they have lost everything for the sake of winning, they are not satisfied. Thus, they lived in mind of our main character willing to continue on their battle, for it is not the end. Sale being stuck on that planet for while is trapped between these two armies that occupy his mind when he falls asleep. Upon seeing the first battle, upon feeling the danger from these two, he decides not sleep as long as he can.

That is why this work is titled as "Perchance to Dream (Asleep in Armageddon). First title comes from William Shakespeare's tragedy Hamlet in Act 3, Scene -1 where price Hamlet speaks his most famous lines that start with:

To be, or not to be: that is the question:

Whether 'tis nobler in the mind to suffer

The slings and arrows of outrageous fortune,

Or to take arms against a sea of troubles,

And by opposing end them? To die: to sleep;

No more; and by a sleep to say we end

The heart-ache and the thousand natural shocks

That flesh is heir to, 'tis a consummation

Devoutly to be wish'd. To die, to sleep; 
To sleep: perchance to dream: ay, there's the rub;

For in that sleep of death what dreams may come

When we have shuffled off this mortal coil,

Must give us pause: there's the respect

That makes calamity of so long life;

In these lines we see certain doubt about afterlife, about death as the main character, Hamlet, thinks about ending his life, thus to stop the pain of loss that is eating his soul and mind. He is not sure whether death would offer a peace or would death continue torture him even after leaving his physical body. There are certain similarities both in Hamlet and in Perchance to Dream, the theme of death as solution remains to be similar, as the main hero in Perchance to Dream almost commits suicide falling asleep with a gun in his hand, he wanted to kill himself rather than to be a mindless creature occupied by two different armies that are fighting till death in his mind. He wants a peaceful sleep but he can't and thus he is supposed to suffer until a rescue ship arrives. Same with Hamlet, he wants to discard everything but he is not sure about afterlife, as there is a certain doubt about it, no one really knows what is out there. This is not the only intertextual unit taken from "Hamlet", there are plenty lines that suggest that the author wanted his readers to relate the feelings of Hamlet and the main character Sale. For this purpose he extended his literary text with intertextual units.

To die: to sleep;

This expression is seen quite much in the short story Perchance to Dream,

Sleep, sleep, sleep, sleep, sleep, sang the voices.

Ohhhhhhhhhhhh, sang the voices.

Ahhhhhhhhhhhh, sang the voices.

Die, die, die, die, die. Sleep, sleep, die, sleep, die, sleep, die!

Winding up with this story, we should say that the author used intentional intertextuality units, as these units clearly add conceptual seasoning to the story of Ray Bradbury and extend the reach of stories meaning. Living and fighting, both characters value their life, thus intending to fight till the end rather than just to lie down and die. Both literary works end in tragic way, as both of the main characters die while fighting till the end and a suicide was not a solution for both of them.

This is not a the single case where a title carries an additional meaning, we can bring up another story published in 1950 by Collier "There will come soft rains...." by the same author where the title is a direct intertextual reference to the poem written by Sara Teasdale in the July 1918 issue of Harper's Magazine[ Sara T, p. 238 1 ]. The poem is dedicated to the outcomes of the First World War, though, physical possibility of this happening appeared a bit later which Ray Bradbury understood that was why he used the first line of the poem and added the whole poem at the end of the short story itself, directly pointing to an inter-textual reference:

There will come soft rains and the smell of the ground,

And swallows circling with their shimmering sound;

And frogs in the pools singing at night,

And wild plum-trees in tremulous white;

Robins will wear their feathery fire

Whistling their whims on a low fence-wire;

And not one will know of the war, not one

Will care at last when it is done.

Not one would mind, neither bird nor tree

If mankind perished utterly;

And Spring herself, when she woke at dawn, 
Would scarcely know that we were gone [Sara T, p. 238 1]

The plot of the story revolves around the abandoned house which is located in city of Allendale, California, on April 28, 1985. The house stands as self-sufficient, run by inner intelligence, and maintains the basic routine such as preparing breakfast, cleaning and other stuff. The whole description of the house amuses and at the same time disturbs the readers mind, depicting how this smart house gets rid of a dog body, how this house intends to preserve itself from the fire. The plot and the content of the poem are similar, the total annihilation of human race by its destructive nature. We see that human race as such wiped itself out using the tools of war, giving no chance to its own survival. We don't know who started it, and it is not as much important as why the poem is recited at the end. Validity of destructive nature of human race reflected in the poem takes real steps with creation of an atomic bomb and its use on Hiroshima and Nagasaki in 1945, broadly illustrating to which extend it will go. Cold War that took place afterwards brought closer the prediction of Sara Teasdale, thus Ray Bradbury wrote his work using the reference from the poem.

There are several other works in which Ray Bradbury uses direct inter-textual references such as allusions from the Bible, to which we can refer his short story written in 1960 with title "Some live like Lazarus". The title includes allusion to Lazarus of Bethany who was revived by the Jesus Christ after his death according to the Bible. The plot of the story is about a boy, who remains beside his "mother" for far too long, giving up the life which he could get, like a butterfly that remains in its cocoon rather than going out. In the story we see how the main character remains to be always controlled in his life because of his mother, that who makes it miserable.

All his life he was planning to murder her, but never was able to do that to the very end of her life. Though, we don't know for sure whether he killed his "mother" or she died of natural reasons but that is not important. What remains to be import is the freedom which he gains after many years of "prison"; the poetry included into the story by Ray Bradbury suggests the whole intended idea:

\section{Some live like Lazarus}

In a tomb of life

And come forth curious late to twilight hospitals

And mortuary rooms.

Better cold skies seen bitter to the North

Than stillborn stay, all blind and gone to ghost.

If Rio is lost, well, love the Arctic Coast!

$O$ ancient Lazarus

Come ye forth.

The title is not the only an example of inter-textuality but also there are direct inter-textual reference form the Bible which can be seen in the final line of the poem, where "Come ye forth" directly refers to the Bible and to words of Jesus Christ. The idea of the story indicates that some people are living like the dead, while physically remaining to be alive.

"I Sing the Body Electric" is another work written by Ray Bradbury that includes direct intertextual units within itself, that on their turn broaden the conceptual idea reflected in the work. The title refers to the poem written by Walt Whitman in his book which starts with lines:

I sing the body electric,

The armies of those I love engirth me and I engirth them,

They will not let me off till I go with them, respond to them,

And discorrupt them, and charge them full with the charge of the soul. 
Originally, Bradbury's short story was created few years after its initial show in TV series The Twilight Zone in 1962, and was titled as "The Beautiful One is Here" but was later renamed as "I Sing the Body Electric" when it was published in 1969 [ Bradbury , 3].

The plot of the work is about the family and love, the family that has just became incomplete because of the death of a mother, the family that is in distress, in need of some love and attention. As the father still remains to be the breadwinner, he cannot substitute the role of the mother thus he decides to ask for a help from Fantoccini Ltd, a company that specializes in helping such families with a robot that is capable to give the love, attention, and care which is essentially needed for children after the death of their mother. Here, in this work, we are able to see the notion of the soul, concept of the love and how these things make a mechanical robot to become the grandmother that is like a human being. The robot which specializes in giving the love, not an artificial love but true unconditional love that has intended to make children happy, to fulfill the gap that is left after their mother's death. This type of robots remain to be quite different, for they exist for others, for they exist to make families complete. They serve well in hope that someday they will be able to become alive, like Pinocchio from the tale and being good grandmothers is a key and they live to make that dream come true. They know it is just a dream, but nevertheless doing their best for the purpose creator intended them to be, loved by children by the love they give. To which we become sure reading the second line of the poem and the story itself. Even if a grandmother's love would cost her life, she should accept it as any other loving mother does, for the love is the meaning of their existence.

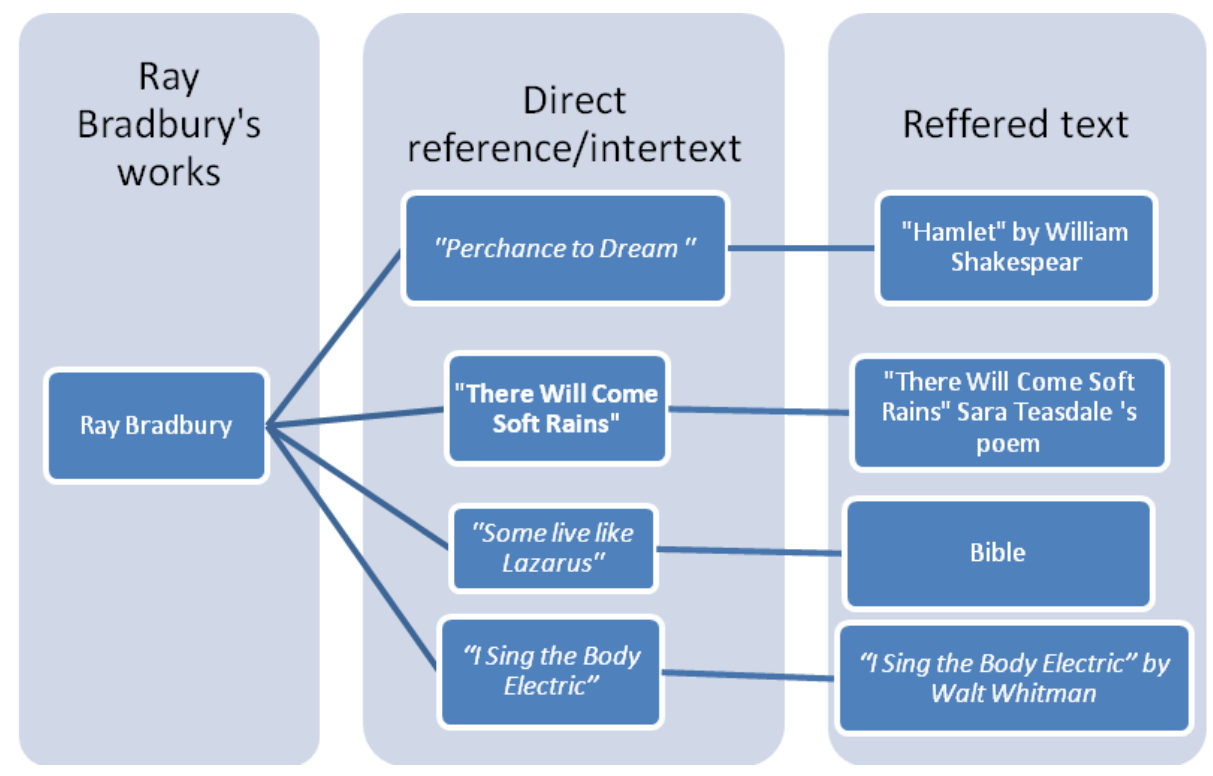

The plot and the meaning of the poem written by Walt Whitman meet similar themes, thus the author decided to pick up the first line of poem. The poem prizes human beings as they are the perfection of this world, their body, their soul, each and every part that works almost like the grinds of machine make them perfect in all sense.

In conclusion we can see that the vast usage of an intertext indeed helps us to comprehend the works of Ray Bradbury, suggesting us to read more in order to understand a conceptual idea of the work, enforcing the deeper meaning into the context through other literary texts. Such vast usage of an intertext in the title along the way helping to broaden a conceptual idea, works as a trigger that intends to capture the interest of readers of Ray Bradbury's story who might have read the referred text before reading, thus curiosity lures them to read a new text that has an intertext, increasing the 
amount of experience gained through reading new text. It is evident that literature as such intends to aid us to comprehend the world better, and new texts function succeeds in completing this task.

References:

1. Harper's Magazine (July 1918). CXXXVII, 238

2. Short Stories Cross-Reference. (2013).

Работа поступила

Принята к публикациии

в редакцию 29.04.2019 2.

05.05.2019 2.

Ссылка для циитирования:

Mansurov R. Title Intertextuality in Ray Bradbury's Works // Бюллетень науки и практики. 2019. T. 5. №6. C. 535-540. https://doi.org/10.33619/2414-2948/43/77

Cite as (APA):

Mansurov, R. (2019). Title Intertextuality in Ray Bradbury's Works. Bulletin of Science and Practice, 5(6), 535-540. https://doi.org/10.33619/2414-2948/43/77 